\title{
Effect of oral glucose administration on ghrelin levels in obese children
}

\author{
Leandro Soriano-Guillén, Vicente Barrios, Gabriel Martos, Julie A Chowen, Angel Campos-Barros and \\ Jesús Argente \\ Department of Pediatric Endocrinology and Laboratory of Research, Universidad Autónoma, Hospital Infantil Universitario Niño Jesús, \\ Avda. Menéndez Pelayo 65, E-28009 Madrid, Spain \\ (Correspondence should be addressed to J Argente; Email: argentefen@terra.es)
}

\begin{abstract}
Objective: Coexpression of GH secretagogue receptor and ghrelin in the pancreas suggests that this peptide is involved in glucose metabolism. Previous reports in adult humans have demonstrated that plasma ghrelin levels decrease after oral glucose administration. However, no data are available in children. Therefore, the aim of this study was to analyze the response of plasma ghrelin levels in obese children after oral glucose administration.

Subjects and methods: Twenty-eight obese children ranging from Tanner I to Tanner V were studied. All subjects were given $0.75 \mathrm{~g} / \mathrm{kg}$ (maximum $75 \mathrm{~g}$ ) glucose solution after overnight fasting. Ghrelin, insulin, glucose and IGF-binding-protein-1 were determined at 0, 30, 60 and $120 \mathrm{~min}$ of the oral glucose tolerance test (OGTT).

Results: Basal plasma ghrelin levels were significantly lower than in the respective control groups. These levels decreased significantly during OGTT in obese children, reaching a nadir of $28 \pm 9 \%$ at $60 \mathrm{~min}$ in parallel with the maximum increase in glucose levels and previous to maximum insulin levels.

Conclusion: The rapid fall in plasma ghrelin concentration in obese children after glucose load suggests a mechanism for the control of appetite after food intake.
\end{abstract}

European Journal of Endocrinology 151 119-121

\section{Introduction}

Ghrelin is an acylated 28 amino acid peptide produced predominantly by the stomach (1), although a minor proportion of ghrelin synthesis occurs in other sites such as the hypothalamus, pituitary and lung (2). Coexpression of ghrelin and growth hormone receptor within the endocrine pancreas suggests that ghrelin could be implicated in glucose metabolism (2-4). However, conflicting results have been reported concerning the influence of ghrelin on insulin secretion (5-8). On the other hand, evidence suggests that glucose administration decreases ghrelin levels $(7,9)$, while ghrelin administration induces hyperglycemia (10). It is known that obese children have decreased circulating ghrelin levels (11) and elevated insulin levels (12), but to our knowledge there are no data on ghrelin levels after glucose oral administration in obese children.

In order to investigate the effect of glucose on ghrelin levels, we measured ghrelin levels at fasting and during an oral glucose tolerance test (OGTT) in obese children. The relationship with other parameters involved in glucose metabolism, such as insulin, glucose and insulin-like growth factor-binding protein-1 (IGFBP-1) levels were also analyzed at each time-point during the OGTT.

\section{Subjects and methods}

\section{Subjects}

Twenty-eight obese children (17 boys and 11 girls), aged 13.2 \pm 3.4 years, were included in this study. These patients had a body mass index (BMI) greater than 2 S.D. above Spanish standards (13). They were at different Tanner stages of pubertal development (Tanner I: 7, Tanner II: 4, Tanner IV: 5 and Tanner $\mathrm{V}:$ 12). The obese children had a mean BMI of 5.81 \pm 3.37 and had no other known endocrine disorder and were receiving no medication at the time of the study. Ghrelin levels were compared with values in a control population reported previously (14).

All subjects were informed about the purpose of the study and parents or guardians gave consent. 
This study was approved by the local human ethics committee.

\section{Methods}

All subjects were given $0.75 \mathrm{~g} / \mathrm{kg}$ (maximum $75 \mathrm{~g}$ ) glucose solution orally after overnight fasting. Blood was withdrawn from a catheter at $0,30,60$ and $120 \mathrm{~min}$ during the OGTT and kept in chilled tubes containing EDTA $(1 \mathrm{mg} / \mathrm{ml})$ plus aprotinin $(500 \mathrm{U} / \mathrm{ml})$. The tubes were centrifuged and stored at $-80^{\circ} \mathrm{C}$ until assayed.

Plasma ghrelin levels were measured by a commercial radioimmunoassay (Phoenix Pharmaceutical, Inc., Belmont, CA, USA) using a polyclonal antibody that recognizes octanoylated and non-octanoylated ghrelin and ${ }^{125} \mathrm{I}$-ghrelin as a tracer molecule. The intra- and interassay coefficients of variation were $5.0 \%$ and $11.2 \%$ respectively. Assay sensitivity was $12 \mathrm{pg} / \mathrm{ml}$.

IGFBP-1 and insulin levels were measured as reported previously (12). Plasma glucose was measured by the glucose oxidase method on a Beckman Glucose Analyzer (Fullerton, CA, USA).

\section{Statistics}

All data are reported as the means \pm S.D. Analysis was performed by ANOVA for repeated measures, followed by Scheffe's F test; $P<0.05$ was chosen as the level of significance. Multiple regression analysis was performed to determine the overall interaction of the parameters studied, followed by partial correlation analysis.

\section{Results}

A significant decrease in ghrelin levels was found after oral glucose administration, with a maximum decrease of $28 \%$ occurring at $60 \mathrm{~min}$ after glucose intake. In contrast, insulin and glucose concentrations were increased after glucose intake, with maximum levels found at 60 and $120 \mathrm{~min}$ for glucose and insulin respectively. We found no differences in IGFBP-1 levels after glucose administration (Fig. 1).

When the relationship between ghrelin and insulin, glucose and IGFBP-1 was analyzed, a positive correlation between ghrelin and IGFBP-1 levels was found only at $0 \min (r=0.58, P<0.01)$, but at no other time-point. No correlation between ghrelin and glucose or insulin was observed at any time-point. There was no correlation between ghrelin levels and insulin resistance: $($ HOMA- $R=$ glucose $($ in $\mathrm{mg} / \mathrm{dl}) \times$ insulin (in $\mu \mathrm{U} / \mathrm{l}) / 405$ ).

\section{Discussion}

We have here demonstrated that although ghrelin levels were significantly decreased in obese children, oral glucose administration decreased circulating ghrelin levels further. This is in agreement with previous
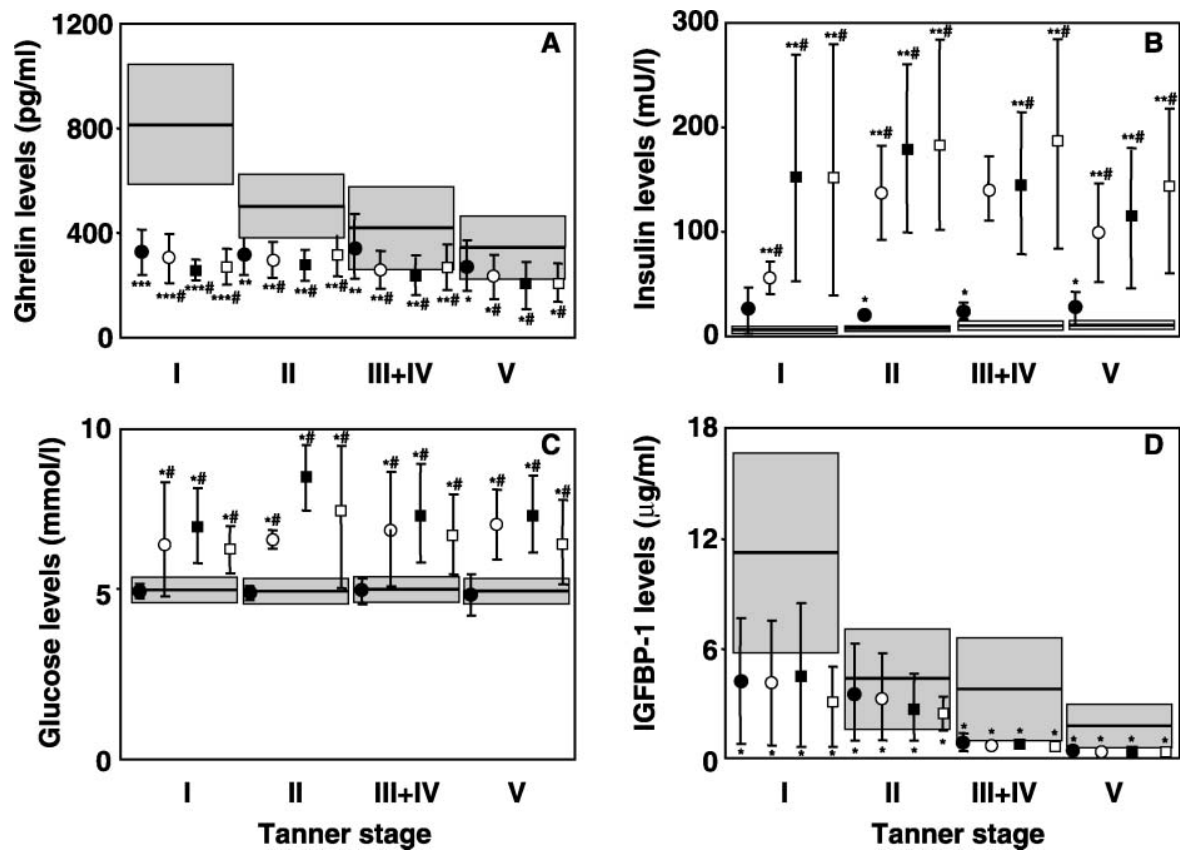

Figure 1 Representation of basal serum levels of (A) ghrelin, (B) insulin, (C) glucose and (D) IGFBP-1 concentrations ( $\bullet$ ) in obese children and $30 \mathrm{~min}(O), 60 \mathrm{~min}(\square)$ and $120 \mathrm{~min}(\square)$ after glucose administration compared with puberty-matched control values, indicated by the shaded areas which represent the mean \pm 1 S.D. ${ }^{*} P<0.05,{ }^{*} P<0.01,{ }^{* \star *} P<0.001$ vs control values; ${ }^{\#} P<0.05$ vs basal values. 
reports showing that plasma ghrelin levels are significantly decreased after oral glucose ingestion $(7,9)$.

The maximum decrease in ghrelin levels was reached in parallel with the maximum increase in glucose concentrations and occurred before insulin levels reached their maximum. Inversely, ghrelin administration induced hyperglycemia and this effect was unrelated to the decrease in insulin, as this decrease occurred after the increase in glucose concentrations (10). Indeed, we have previously reported a negative correlation between ghrelin and glucose concentrations throughout normal development with no relationship to basal insulin levels (14). Furthermore, ghrelin levels were decreased in diabetic children and remained low despite insulin therapy (15). Taken together, these results suggest that circulating glucose levels modulate ghrelin concentrations and that ghrelin-producing cells may respond directly to changes in plasma glucose concentrations (7).

Our data have confirmed that the maximum decrease in ghrelin levels is at $60 \mathrm{~min}$ after glucose administration $(7,9)$. The rapid decrease in ghrelin levels observed as early as $30 \mathrm{~min}$ after glucose administration is similar to that observed after administration of a meal (7), indicating that this peptide is probably implicated in the rapid control of food intake. However, after oral glucose administration the decrease in ghrelin levels with respect to basal values was only $28 \%$ in obese children, while in normal adults it reached approximately $60 \%(7,9)$ and in anorexic patients $50 \%$ (9). One possibility is that the glucose-induced decrease in ghrelin levels is less accentuated in obese children because their basal levels are already low (11). Another possible explanation is that these patients are hyperinsulinemic with a certain degree of insulin resistance, suggesting that there may be a modification in their glucose-sensing system.

Although ghrelin and IGFBP-1 had a positive relationship before glucose administration, this correlation was not seen at later time-points. A possible explanation is that IGFBP-1 levels are very low in obese children (12) and remain so in spite of insulin elevation during OGTT, suggesting insulin resistance, as has been previously reported (16). The correlation between IGFBP-1 and ghrelin at baseline could be due to the fact that these two factors are secreted in a parallel pulsatile fashion.

In conclusion, our results showed a link between glucose concentrations and ghrelin levels, suggesting that ghrelin may have an effect over the endocrine pancreas, as well as with the control of food intake.

\section{Acknowledgements}

This work was supported by a grant from the Ministerio de Cieñcia y Technología (SAF 2002-03324) and Fundación Endocrinología y Nutrición. AC-B was supported by a grant from the Fondo de Investigación Sanitaria (exp. 003145).

\section{References}

1 Kojima M, Hosoda H, Date Y, Nakazato M, Matsuo H \& Kangawa K. Ghrelin is a growth-hormone-releasing acylated peptide from stomach. Nature $1999 \mathbf{4 0 2}$ 656-660.

2 Gnanapavan S, Kola B, Bustin SA, Morris DG, McGee P, Fairclough P, Bhattacharya S, Carpenter R, Grossman AB \& Korbonits M. The tissue distribution of the mRNA of ghrelin and subtypes of its receptor, GHS-R in humans. Journal of Clinical Endocrinology and Metabolism 200287 2988-2991.

3 Wierup N, Svensson H, Mulder H \& Sundler F. The ghrelin cell: a novel developmentally regulated islet cell in the human pancreas. Regulatory Peptides $2002 \mathbf{1 0 7} 63-69$.

4 Rindi G, Necchi V, Savio A, Torsello A, Zoli M, Locatelli V, Raimondo F, Cocchi D \& Solcia E. Characterisation of gastric ghrelin cells in man and other mammals: studies in adult and fetal tissues. Histochemistry and Cell Biology $2002117511-519$.

5 Adeghate E \& Ponery AS. Ghrelin stimulates insulin secretion from the pancreas of normal and diabetic rats. Journal of Neuroendocrinology 200214 555-560.

6 Egido EM, Rodríguez-Gallardo J, Silvestre RA \& Marco J. Inhibitory effect of ghrelin on insulin and pancreatic somatostatin secretion. European Journal of Endocrinology 2002146 241-244.

7 Shiiya T, Nakazato M, Mizuta M, Date Y, Mondal MS, Tanaka M, Nozoe S, Hosoda H, Kangawa K \& Matsukura S. Plasma ghrelin levels in lean and obese humans and the effect of glucose on ghrelin secretion. Journal of Clinical Endocrinology and Metabolism 2002 $87240-244$.

8 Schaller G, Schmidt A, Pleiner J, Woloszczuk W, Wolzt M \& Luger A. Plasma ghrelin concentrations are not regulated by glucose or insulin: a double-blind, placebo-controlled crossover clamp study. Diabetes 200352 16-20.

9 Nakai Y, Hosoda H, Nin K, Ooya C, Hayashi H, Akamizu T \& Kangawa K. Plasma levels of active form of ghrelin during oral glucose tolerance test in patients with anorexia nervosa. European Journal of Endocrinology 2003149 R1-R3.

10 Broglio F, Benso A, Castiglioni C, Gottero C, Prodam F, Destefanis S, Gauna C, van der Lely AJ, Deghenghi R, Bo M, Arvat E \& Ghigo E. The endocrine response to ghrelin as a function of gender in humans in young and elderly subjects. Journal of Clinical Endocrinology and Metabolism 200388 1537-1542.

11 Soriano-Guillén L, Barrios V, Campos-Barros A \& Argente J. Ghrelin levels in obesity and anorexia nervosa: effect of weight reduction or recuperation. Journal of Pediatrics $200414436-42$.

12 Argente J, Caballo N, Barrios V, Pozo J, Muñoz MT, Chowen JA \& Hernandez M. Multiple endocrine abnormalities of the growth hormone and insulin-like growth factor axis in prepubertal children with exogenous obesity: effect of short- and long-term weight reduction. Journal of Clinical Endocrinology and Metabolism 199782 2076-2083.

13 Hernández M, Castellet J, Narvaiza JL, Rincón JM, Ruiz I, Sánchez E, Sobradillo B \& Zurimendi A. In Curvas y Tablas de Crecimiento. Eds M Hernández \& Fundación F Orbegozo. Madrid: Editorial Garsi, 1988.

14 Soriano-Guillén L, Barrios V, Chowen JA, Sanchez I, Vila S, Quero J \& Argente J. Ghrelin levels from fetal life through early adulthood: relationship with endocrine and metabolic and anthropometric measures. Journal of Pediatrics 2004144 30-35.

15 Soriano-Guillén L, Barrios V, Lechuga-Sancho A, Chowen JA \& Argente J. Response of circulating ghrelin levels to insulin therapy in children newly diagnosed with type 1 diabetes mellitus. Pediatric Research $2004551-6$.

16 Rutanen EM, Karkkainen T, Stenman UH \& Yki-Jarvinen H. Aging is associated with decreased suppression of insulin-like growth factor binding protein-1 by insulin. Journal of Clinical Endocrinology and Metabolism 199377 1152-1155.

Received 23 December 2003

Accepted 18 March 2004 